\title{
Action of Thiocarbamate Herbicide Dimepiperate on Plant Metabolism*
}

\author{
Hiroshi Matsumoto**, Seiko Nishi**,*** and Kozo Ishizuka**
}

\begin{abstract}
Phytotoxic activity of the thiocarbamate herbicide dimepiperate (S-1-methyl-1-phenylethyl piperidine-1-carbothioate) and its effect on plant metabolism were investigated. The chemical was highly selective against tested monocotyledonous plants. Rice and corn showed strong tolerance, while barnyardgrass and crabgrass were susceptible to the herbicide. Dicotyledonous plants were tolerant.
\end{abstract}

Dimepiperate $\left(10^{-5} \mathrm{M}\right)$ reduced ${ }^{14} \mathrm{C}$-acetate incorporation into lipid fraction in leaf disks of barnyardgrass more than $30 \%$ at $60 \mathrm{~min}$ after incubation. Lipid synthesis inhibitor, cerulenin, caused the same level of reduction of the acetate incorporation at $10^{-5} \mathrm{M}$, and this incorporation was inhibited even with $10^{-6} \mathrm{M}$ dimepiperate.

Reduction of ${ }^{14} \mathrm{C}$-leucine and ${ }^{14} \mathrm{C}$-glucose incorporation into protein and cell wall fraction, respectively, were detected at $120 \mathrm{~min}$ with $10^{-5} \mathrm{M}$. None of RNA and DNA synthesis, photosynthesis or respiration was affected by the herbicide. The results suggest that the primary site of action of dimepiperate is in the lipid synthesis pathway.

Key words: thiocarbamate herbicide, dimepiperate, selectivity, mode of action, lipid

\footnotetext{
*A part of this work was presented at the 28 th Annual Meeting of the Weed Science Society Japan (1989).

**Institute of Applied Biochemistry, University of Tsukuba, Tsukuba, Ibaraki 305, Japan

***Present address : Tsukuba Research Center, Mitsubishi Petrochemical Co. Ltd., Inashiki, Ibaraki 30003, Japan

(Received January 12,1991)
}

synthesis inhibition.

\section{Introduction}

Dimepiperate(S-1-methyl-1-phenylethyl piperidine-1-carbothioate), a newly developed thiocarbamate herbicide, controls barnyardgrass and other grass weeds in paddy rice. Ikeda $^{6)}$ reported that dimepiperate was very safe to rice plant. Although the mechanism is still unknown, safening effect of dimepiperate to several herbicides with different types of chemical structure was also reported ${ }^{7)}$.

The mode of action of certain thiocarbamate herbicides has been investigated in detail. EPTC (S-ethyl dipropylthiocarbamate) inhibited growth of the meristematic region of grass leaves ${ }^{2}$. With herbicide treatment the first leaf is often trapped in the coleoptile and emerges from the side of the coleoptile grossly distorted. Ashton et $a l^{1}$. reported that EPTC inhibited photosynthesis and respiration as well as synthesis of lipid, protein and RNA. The inhibition of gibberellic acid (GA) synthesis has also been reported. Certain symptoms of EPTC injury such as leaf sheath stunting are characteristic of GA deficiency and are reduced by the application of $\mathrm{GA}^{3,12)}$. Recently, Wilkinson and Oswald ${ }^{13)}$ reported inhibition of an acetyl-CoA synthesizing enzyme by the chemical at low concentration.

Compared with EPTC and other thiocarbamate herbicides used for upland crops, there is less information on the mode of action of thiocarbamates for paddy rice. Thiobencarb was reported to inhibit protein synthesis ${ }^{8)}$, and recently to inhibit porphyrin 
metabolism in susceptible plant species ${ }^{11)}$; however, the primary site of action of thiobencarb is still unclear. Moreover, no information has been available on the mode of action of dimepiperate.

The purposes of the study were to determine phytotoxic activity of dimepiperate to various plant species and to compare the effect of the chemical on several metabolic processes in plants.

\section{Materials and Methods}

\section{Radiolabeled chemicals}

${ }^{14} \mathrm{C}$ or ${ }^{3} \mathrm{H}$-Labeled precursors were purchased from DuPont (USA) and Amersham (England). Their specific activities were 9. 24, $11.08,12.97,7.30$ and $1.51 \mathrm{MBq} / \mathrm{mmol}$ for $1-\left[\mathrm{U}-{ }^{14} \mathrm{C}\right]$ leucine, $\left[{ }^{3} \mathrm{H}(\mathrm{G})\right]$ uridine, $\left[\right.$ methyl- $\left.{ }^{3} \mathrm{H}\right]$ thymidine, D-[U- $\left.{ }^{14} \mathrm{C}\right]$ glucose and $\left[1-{ }^{14} \mathrm{C}\right]$ acetic acid, respectively.

\section{Plant materials}

Seeds of rice(Oryza sativa L. cv. Nipponbare), barnyardgrass (Echinochloa oryzicola Vasing.), corn (Zea mays L. cv. Honeybantam), large crabgrass (Digitaria adscendens Henr.), cucumber (Cucumis sativus L. cv. Shimoshirazujibai), tomato (Lycoperisicon esculentum Mill. cv. Toyofuku), radish ( $R a$ phanus sativus L. cv. Tokinashi) and azuki bean (Phaseolus radiatus L., var. aurea PRAIN cv. Waseazuki) were germinated in an incubator at $25^{\circ} \mathrm{C}$ by soaking them in distilled water or wrapping them in moist paper. They were grown to the 3-leaf stage (monocotyledonous plants)or for 3 weeks (dicotyledonous plants) in a growth chamber by nutrient solu tion culture as described elsewhere ${ }^{9)}$. Temperature in the chamber was controlled at $25^{\circ} \mathrm{C}$ for day $(12 \mathrm{hr})$ and at $20^{\circ} \mathrm{C}$ for night. Light intensity was $200 \mu \mathrm{E} / \mathrm{m}^{2} / \mathrm{s}$.

\section{Phytotoxic effect on plants}

Dimepiperate (99\% active ingredient) was dissolved into the nutrient solution with acetone. Final concentration of the solvent was $0.1 \%(\mathrm{v} / \mathrm{v})$. For the herbicide treatment, plants were transferred to plastic bottles which contained $250 \mathrm{ml}$ of the solution. The herbicide concentrations in the nutrient solution were $10^{-7}, 10^{-6}, 10^{-5}$ and $10^{-4} \mathrm{M}$. Solvent control ( $0.1 \%$ acetone) was also prepared. The solutions were renewed every 3 days and the plants were harvested at 9 days. The treatments were carried out with 3 replicates.

\section{Protein, RNA, DNA, lipid and cell wall synthesis}

Leaf disks (2.5 mm diameter) were punched out from the 4 th leaves of barnyardgrass at the 3.4 to 3.8 leaf stage by a cork borer. Twenty disks were placed on $4.9 \mathrm{ml}$ of an incubation medium which consisted of 0.01 $\mathrm{M}$ potassium phosphate buffer $(\mathrm{pH} 6.0), 1 \%$ sucrose and dimepiperate. The final concentration of the herbicide in the medium was $0,10^{-6}$ or $10^{-5} \mathrm{M}$ and that of acetone was $0.1 \%$. The disks were subsequently vacuuminfiltrated in the medium for $15 \mathrm{~min}$, then treated with radiolabeled precursors which are known to be specific to the metabolic process. Radioactivities absorbed by leaf disks and incorporated into the metabolic processes were determined by the methods reported by Hosaka and Kubota-Takagi ${ }^{5)}$ with minor modification.

To study the effect of the herbicide on protein, RNA and DNA synthesis, $0.1 \mathrm{ml}$ of ${ }^{14} \mathrm{C}$-leucine $(18.5 \mathrm{kBq}),{ }^{3} \mathrm{H}$-uridine $(74.0 \mathrm{kBq})$ or ${ }^{3} \mathrm{H}$-thymidine $(74.0 \mathrm{kBq})$ was added to the medium, respectively, at the start of the assay. Glass vials containing the medium and the leaf disks were incubated at $25^{\circ} \mathrm{C}$ in a shaker (40 rpm). At 15, 30, 60, 120 and 240 min, the disks were collected and washed 3 times with a $10^{-3} \mathrm{M}$ solution of each nonlabeled precursor. To determine amounts incorporated into the metabolic process, they were subsequently homogenized with $5 \mathrm{ml}$ of a $5 \%(\mathrm{w} / \mathrm{v})$ TCA solution with a mortar and pestle. After standing in an ice bath for 30 min, the homogenate was filtered with a 
Whatman GF/C glass microfiber filter. Residue on the filter was washed with $5 \mathrm{ml}$ of $5 \%$ cold TCA twice followed by $3 \mathrm{ml}$ of solvents of ethanol, ethanol plus diethyl ether $(1 / 1, v / v)$ and diethyl ether. The filtrates were combined and their radioactivity was determined by liquid scintillation spectrometry. Radioactivity in the solvent insoluble residue was determined similarly after combusting it with a sample oxidizer. Uptake into leaf disks was determined as the total radioactivity in the extract and the residue.

For cell wall synthesis study, the leaf disks were treated with $0.1 \mathrm{ml}(18.5 \mathrm{kBq})$ of ${ }^{14} \mathrm{C}$ glucose. At the above-mentioned intervals, the disks were harvested, washed 3 times with $10^{-3} \mathrm{M}$ of non-labeled glucose solution and homogenized in $5 \mathrm{ml}$ of $0.5 \%(\mathrm{w} / \mathrm{v})$ sodium dodecylsulfate (SDS). The homogenate was filtered with a Whatman $\mathrm{GF} / \mathrm{B}$ glass microfiber filter and the residue on the filter was washed twice with $5 \mathrm{ml}$ of the SDS solution, then with distilled water three times. Radioactivity in the residue was determined as the amount of glucose incorporated into the cell wall. Uptake into leaf disks was determined by total radioactivity in the residue and the extract.

Assay for lipid synthesis was initiated by addition of $0.1 \mathrm{ml}$ of ${ }^{14} \mathrm{C}$-acetate solution $(18.5 \mathrm{kBq})$ to the medium. After harvesting, the disks were frozen and their lipids were extracted with $5 \mathrm{ml}$ of boiling chloroform plus methanol $(1 / 1, \mathrm{v} / \mathrm{v})$ for $5 \mathrm{~min}$. After cooling the extracts in water, the residues were extracted again with $5 \mathrm{ml}$ of a mixture of chloroform, methanol and water (5/10/4, $\mathrm{v} / \mathrm{v} / \mathrm{v})$ in a water bath shaker $\left(25^{\circ} \mathrm{C}\right)$ for 1 hour. To the combined extracts $0.7 \mathrm{ml}$ of $1 \%$ sodium chloride solution and $0.5 \mathrm{ml}$ of chloroform were added. Chloroform and water phases were allowed to separate at least 1 hour. Radioactivity in the chloroform fraction was determined as the amount of acetate incorporated into lipids. Total radioac- tivity of both fractions was determined as uptaken amounts into the leaf disks.

All precursor treatments were made with 3 replicates.

\section{Photosynthesis and respiration}

The leaf disks were placed on $5 \mathrm{ml}$ of incubation medium in glass vials and vacuuminfiltrated. After the herbicide treatment, the vials were kept in the water bath shaker at $25^{\circ} \mathrm{C}$ as mentioned above. At the stipulated periods, the disks were washed with distilled water and transferred to $3 \mathrm{ml}$ of reaction
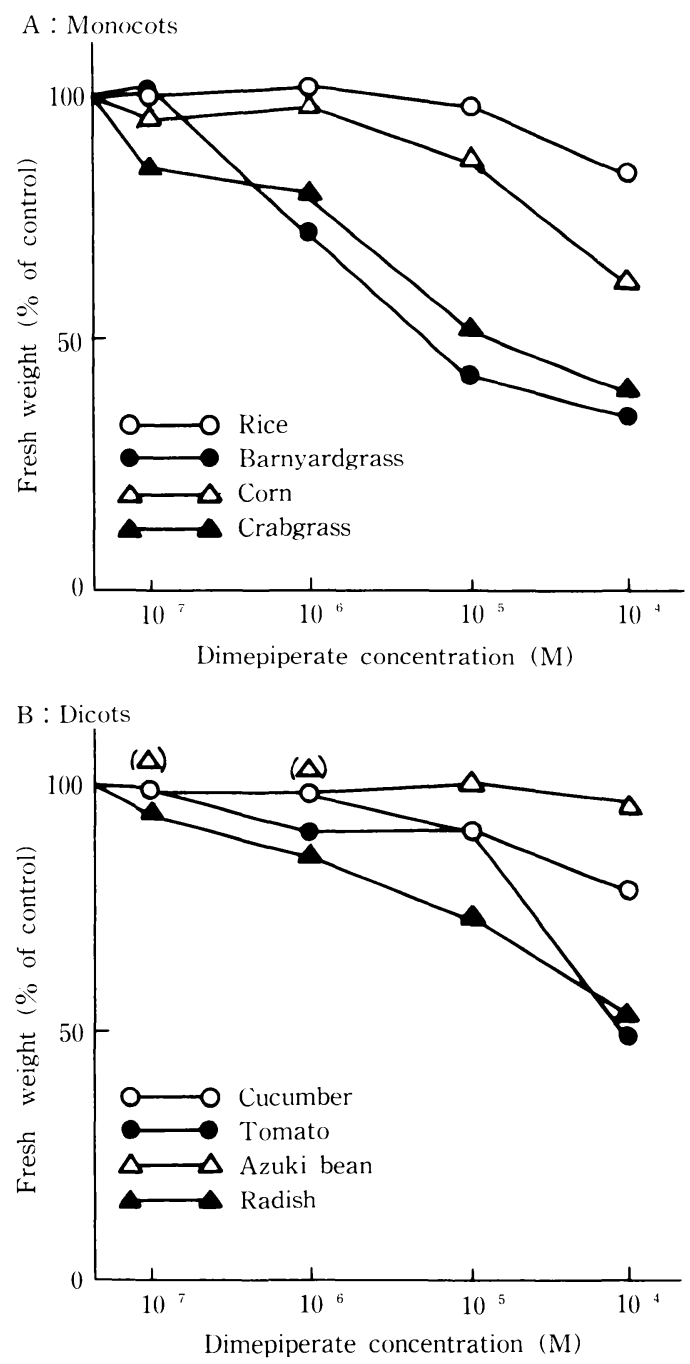

Fig. 1. Phytotoxic activity of root-applied dimepiperate on plant seedlings. Plants were grown in a nutrient solution containing the herbicide for 9 days. 

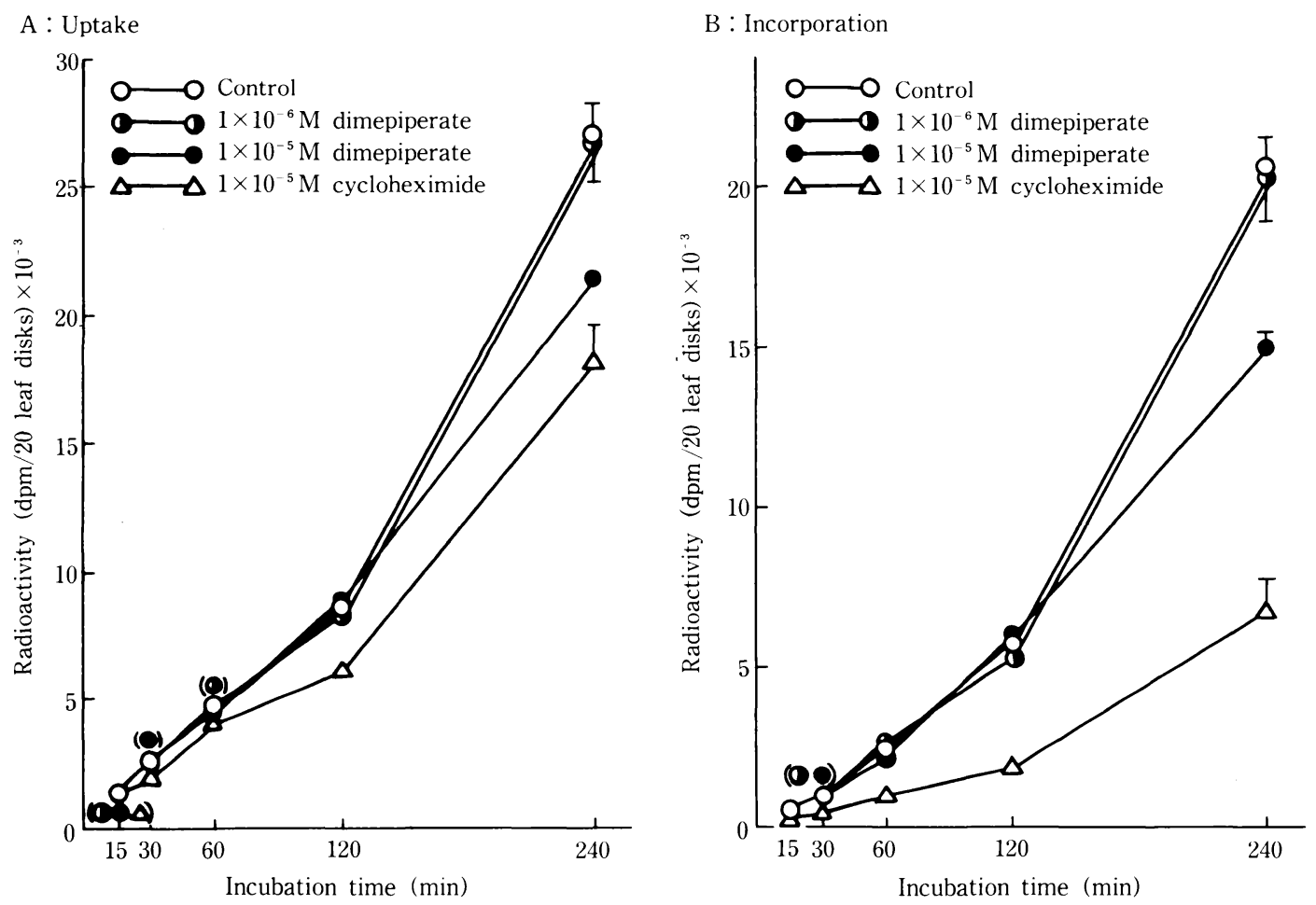

Fig. 2. Effect of dimepiperate on uptake of ${ }^{14} \mathrm{C}$-leucine into leaf disks of barnyardgraes (A) and on its incorporation into protein fraction (B). Bars at 240 min represent standard error.

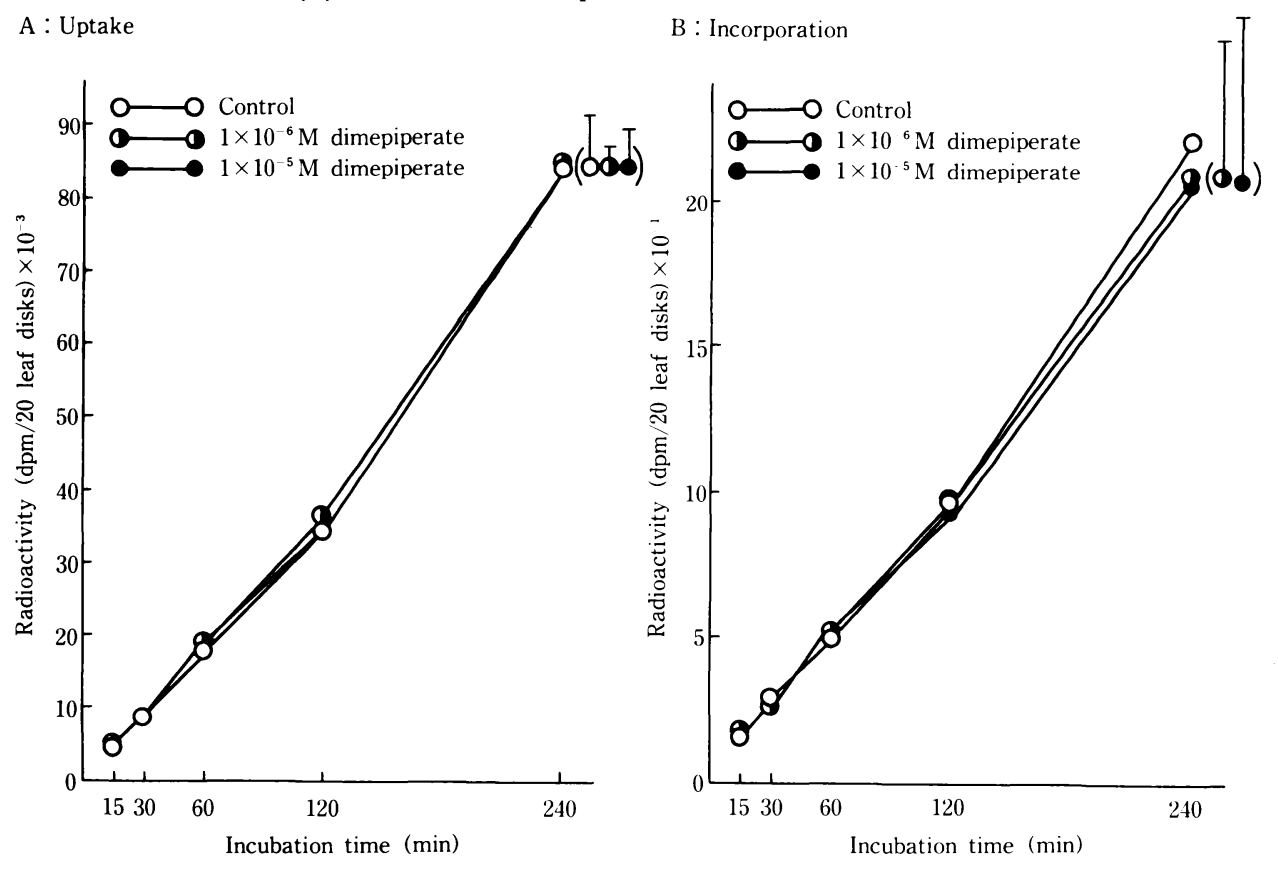

Fig. 3. Effect of dimepiperate on uptake of ${ }^{3} \mathrm{H}$-thymidine into the leaf disks of barnyardgrass (A) and on its incorporation into DNA fraction(B). Bars at $240 \mathrm{~min}$ represent standard error. 
medium which consisted of $0.1 \mathrm{M} \mathrm{NaHCO}$, $0.33 \mathrm{M}$ sorbitol, $1.0 \mathrm{mM} \mathrm{MgCl} 2,2.0 \mathrm{mM} \mathrm{ED}$ $\mathrm{TA}$ and $50 \mathrm{mM}$ HEPES buffer ( $\mathrm{pH} 7.2)$. Oxygen evolution (photosynthesis) and consumption (respiration) in the leaf disks were determined by an oxygen monitor (YSI Model 53) with oxygen electrode as previously described $^{10)}$.

\section{Results}

\section{Phytotoxic effect of dimepiperate on the plants}

Among the tested monocotyledonous plants, barnyardgrass and crabgrass were found more susceptible to dimepiperate than rice and corn (Fig. 1 A). Phytotoxic symptoms were observed in shoots of the susceptible plants even though the herbicide was applied to their roots. The treatment retarded the growth of plants and caused malforming in the emerging 4 th leaves. At higher concentrations plants showed necrosis. Dicotyledonous plants showed higher tolerance than monocotyledons to dimepiperate(Fig. $1 \mathrm{~B}$ ). Tomato and radish showed phytotoxic symptoms only at the highest concentration of the herbicide.

Effect of dimepiperate on protein, $\mathrm{RN}$ $A$, DNA, lipid and cell wall synthesis

Barnyardgrass was selected as a plant ma- terial for the experiments to study the effect of the herbicide on the metabolic processes since it was one of the most susceptible plants to dimepiperate. Leaf disks were prepared from the 4 th leaves of the grass, and uptake and incorporation of the radiolabeled precursors were determined.

No inhibition of ${ }^{14} \mathrm{C}$-leucine uptake into the disks or its incorporation into the protein fraction was observed until $120 \mathrm{~min}$ with $10^{-5} \mathrm{M}$ and $10^{-6} \mathrm{M}$ dimepiperate (Fig. 2). With the treatment of $10^{-5} \mathrm{M}$, however, 19.8 and $28.1 \%$ inhibition of uptake and incorpration were detected after $240 \mathrm{~min}$, respectively (Table 1). Cycloheximide which is known to be an inhibitor of protein biosynthesis in eukaryotic cells strongly inhibited leucine incorporation at the early stage of the experiment (Fig. 2).

At the herbicide concentrations used, neither RNA nor DNA synthesis was affected, even though the incorporation ratio of radioactivity was very small in the metabolic processes (Figs. 3 and 4).

Cell wall synthesis determined by glucose incorporation was inhibited $21.7 \%$ at the higher concentration of the herbicide at 240 min (Fig. 5, Table 1). However, no effect on the uptake was detected up to that time.

Table 1. Effect of dimepiperate on uptake and incorporation of radiolabeled precursors into leaf disks and metabolic processes.*

\begin{tabular}{|c|c|c|c|c|c|c|c|}
\hline \multirow{2}{*}{$\begin{array}{l}\text { Dimepiperate } \\
\text { concentration } \\
\text { (M) }\end{array}$} & \multirow{2}{*}{$\begin{array}{l}\text { Incubation } \\
\text { time } \\
\text { (min) }\end{array}$} & \multicolumn{2}{|c|}{${ }^{14} \mathrm{C}$-leucine } & \multicolumn{2}{|c|}{${ }^{14} \mathrm{C}$-glucose } & \multicolumn{2}{|c|}{${ }^{14} \mathrm{C}$-acetate } \\
\hline & & uptake & incorp. & uptake & incorp. & uptake & incorp. \\
\hline & & & 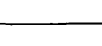 & $-\%$ & $\mathrm{rol}$ & 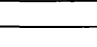 & \\
\hline \multirow{5}{*}{$10^{-6}$} & 15 & 103.6 & 115.3 & 100.3 & 93.3 & 102.4 & 97.8 \\
\hline & 30 & 98.1 & 100.1 & 100.7 & 99.0 & 93.0 & 89.8 \\
\hline & 60 & 100.4 & 104.9 & 98.3 & 98.1 & 95.1 & 86.6 \\
\hline & 120 & 96.0 & 93.5 & 101.8 & 93.9 & 93.0 & 85.3 \\
\hline & 240 & 98.2 & 97.8 & 100.5 & 107.5 & 95.0 & 85.6 \\
\hline \multirow{5}{*}{$10^{-5}$} & 15 & 100.6 & 86.9 & 100.6 & 102.2 & 98.3 & 94.0 \\
\hline & 30 & 99.5 & 101.0 & 99.4 & 98.0 & 93.6 & 85.5 \\
\hline & 60 & 92.4 & 87.1 & 98.6 & 94.4 & 83.2 & 68.7 \\
\hline & 120 & 102.7 & 105.9 & 100.3 & 95.8 & 77.9 & 69.0 \\
\hline & 240 & 80.2 & 71.9 & 95.4 & 78.3 & 83.2 & 66.5 \\
\hline
\end{tabular}

*Data are taken from Figs.2, 5 and 6. 


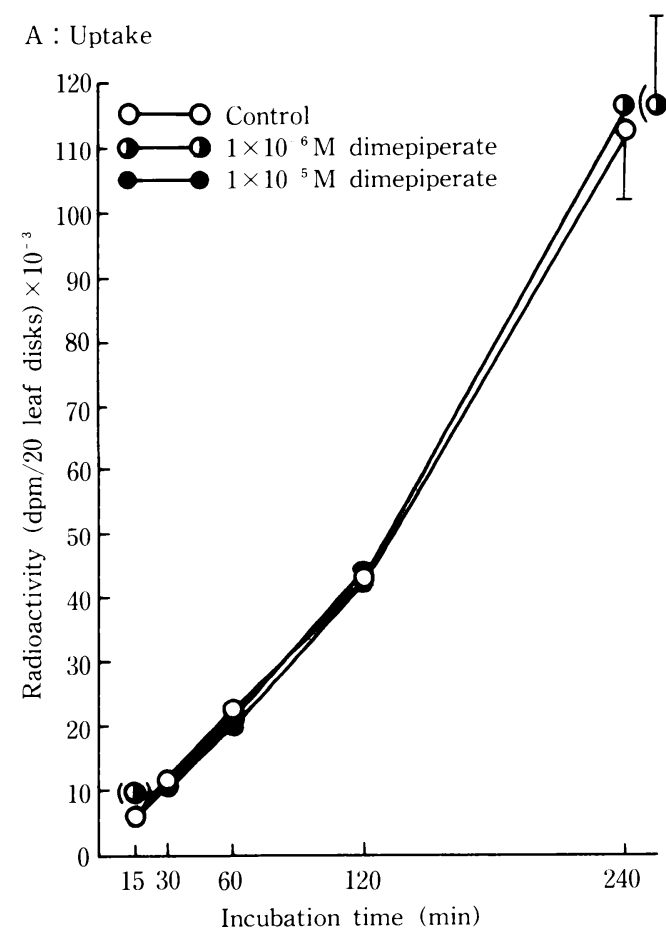

B : Incorporation

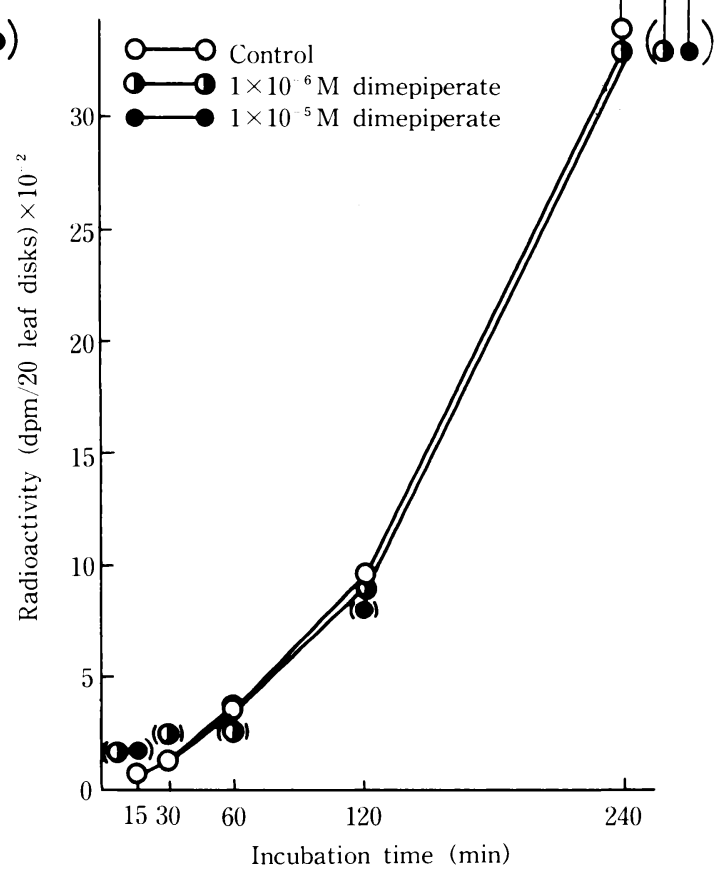

Fig. 4. Effect of dimepiperate on uptake of ${ }^{3} \mathrm{H}$-uridine into the leaf disks of barnyardgrass (A) and on its incorporation into RNA fraction (B). Bars at 240 min represent standard error.
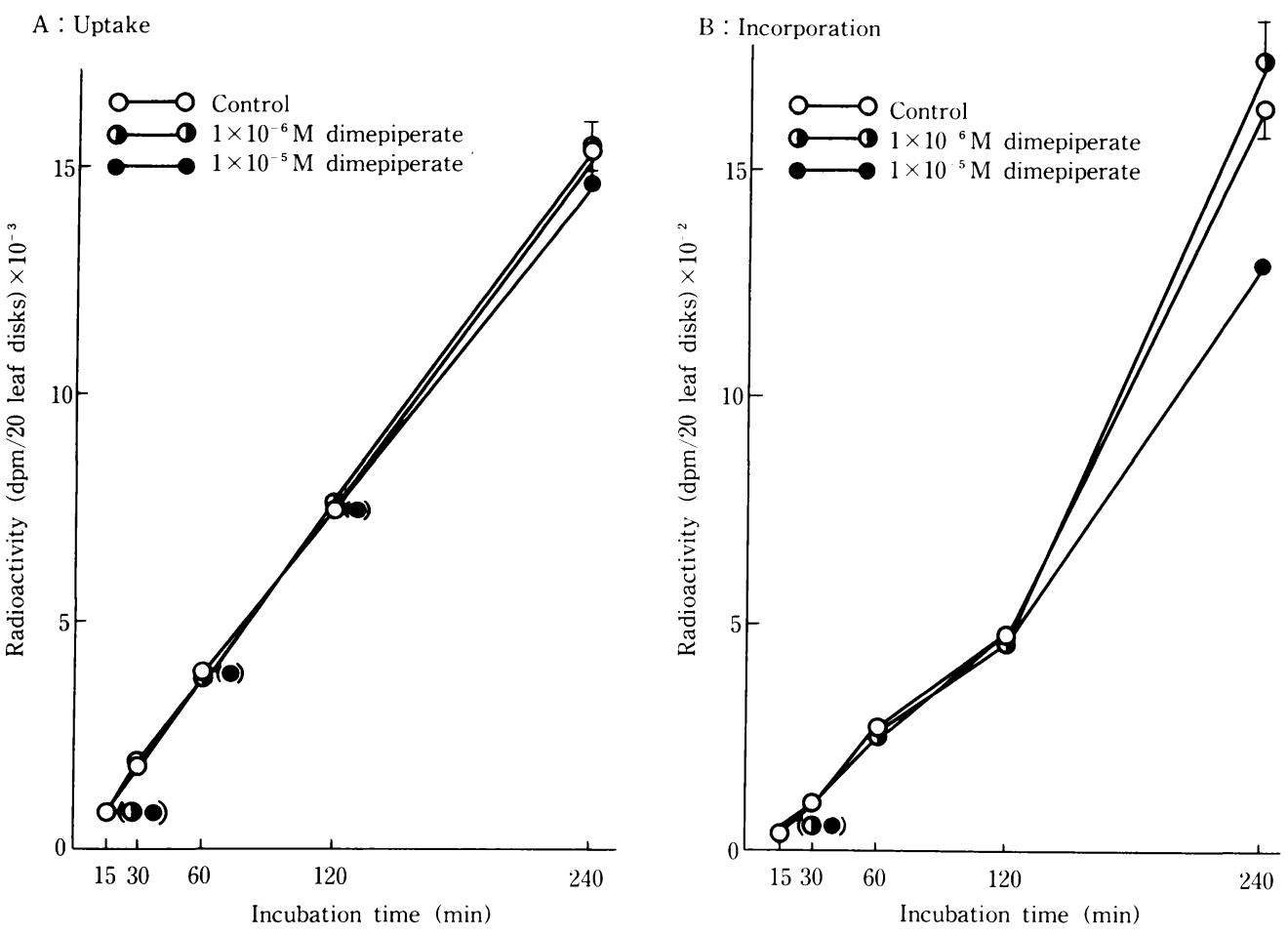

Fig. 5. Effect of dimepiperate on uptake of ${ }^{14} \mathrm{C}$-glucose into the leaf disks of barnyardgrass (A) and on its incorporation into cell wall fraction (B). Bars at $240 \mathrm{~min}$ represent standard error. 


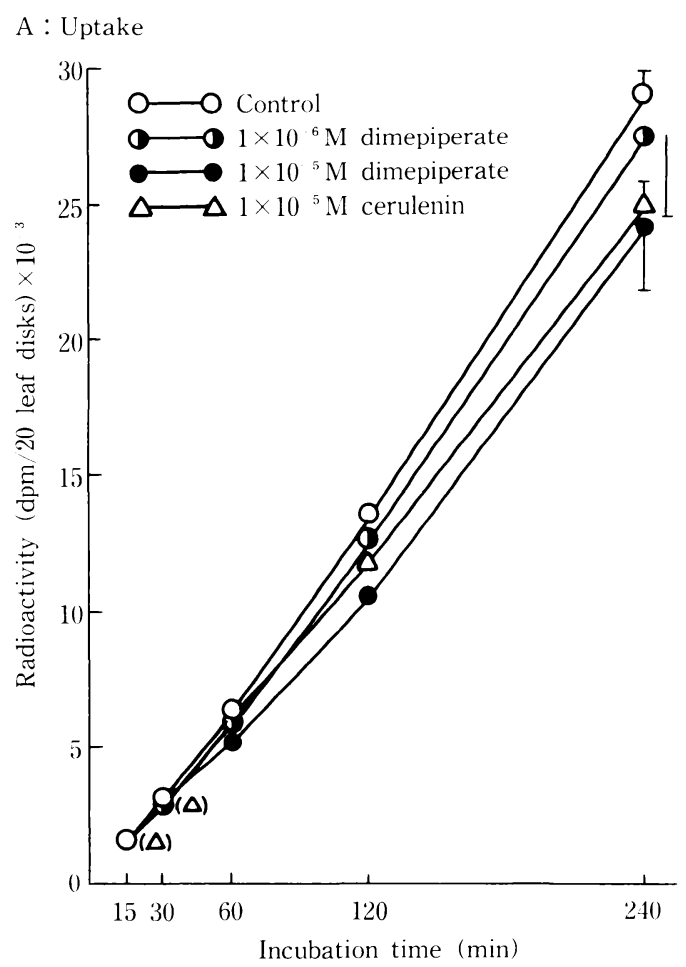

B : Incorporation

Fig. 6. Effect of dimepiperate on uptake of ${ }^{14} \mathrm{C}$-acetic acid into the leaf disks of barnyardgrass (A) and on its incorporation into lipid fraction (B). Bars at $240 \mathrm{~min}$ represent standard error.

Acetate uptake into the disks and its incorporation into the lipid were found to be processes sensitive to dimepiperate (Fig. 6). Incorporation was inhibited 13.4 and $31.3 \%$ at $10^{-6}$ and $10^{-5} \mathrm{M}$, respectively, even at 60 min (Table 1); however, this inhibition rate did not increase thereafter up to $240 \mathrm{~min}$. The fatty acid synthesis inhibitor, cerulenin $\left(10^{-5} \mathrm{M}\right)$, reduced the acetate incorporation by almost the same rate as dimepiperate (Fig. 6).

\section{Effect of dimepiperate on photosyn-} thesis and respiration

Rates of photosynthesis and respiration were determined by measuring $\mathrm{O}_{2}$ evolution and absorption by leaf disks. DCMU, a photosynthetic electron transport inhibitor, remarkably inhibited $\mathrm{O}_{2}$ evolution at $10^{-5} \mathrm{M}$. How ever, the same concentration of dimepiperate showed no inhibition to either process (Fig. 7).

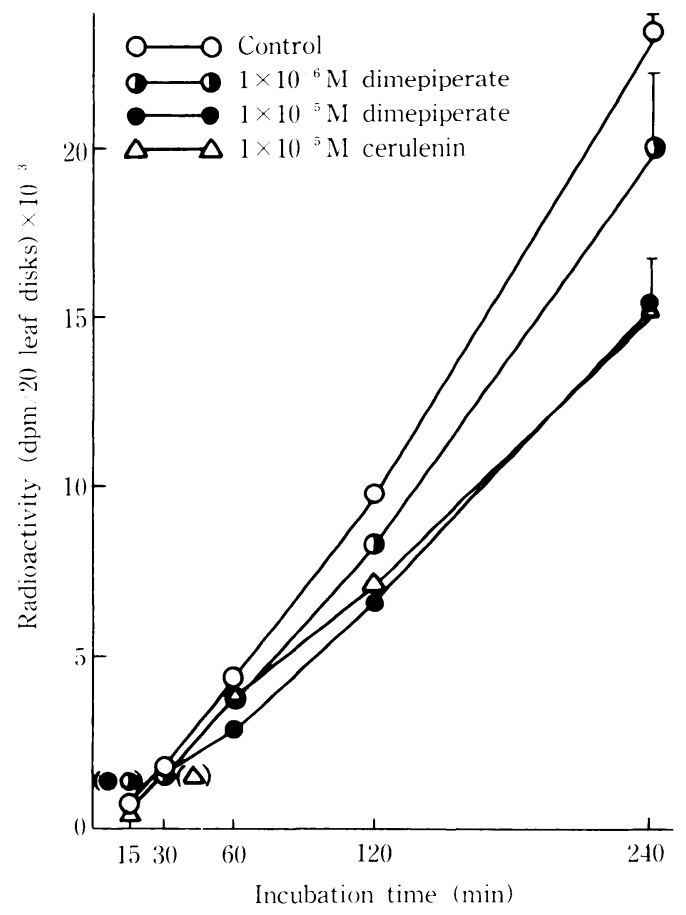



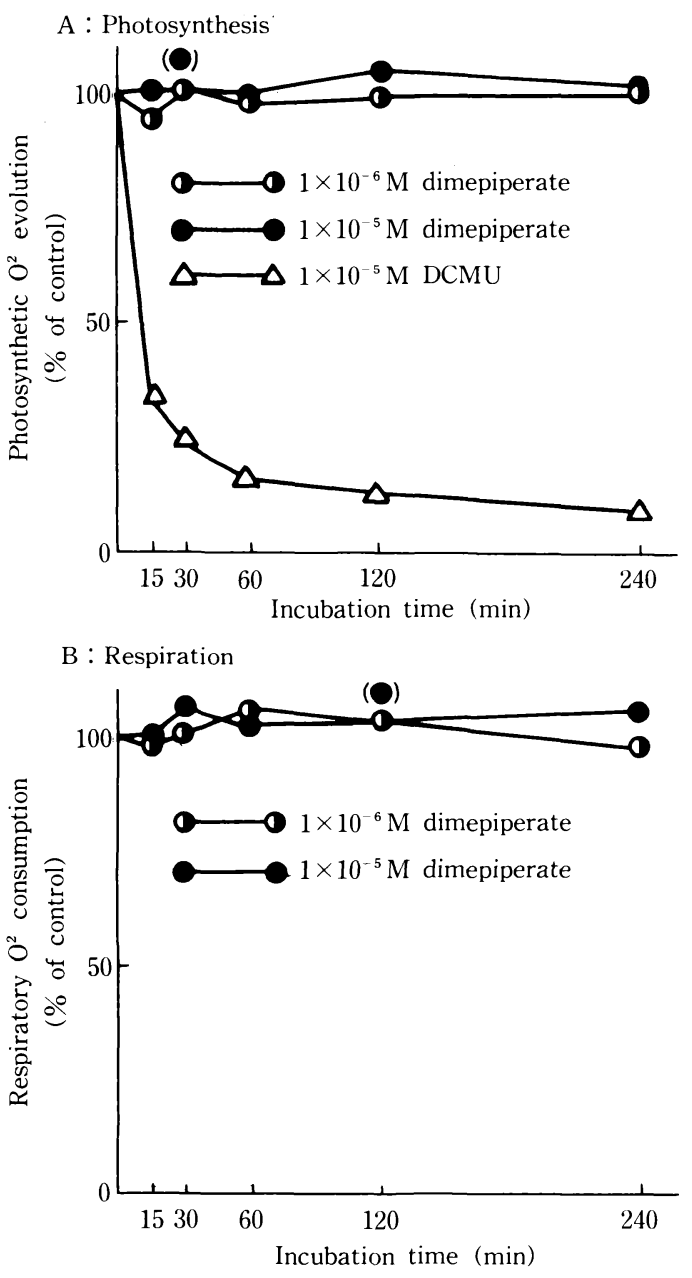

Fig. 7. Effect of dimepiperate on photosynthesis (A) and respiration (B) in the leaf disks of barnyardgrass.

almost the same as that by cerulenin, suggesting that a primary action site of the herbicide is in the lipid synthesis pathway. Leucine and glucose incorporation into protein and cell wall, respectively, were also inhibited. However, these inhibitions are considered a secondary effect of the chemical since they were found later at higher concentrations.

Recently, the inhibitory effects of EPTC on acetyl-CoA synthesis ${ }^{13)}$ and its metabolism ${ }^{4}$ were reported. Acetyl-CoA is a key material of lipid synthesis and is also in- volved in many other metabolic processes in plants, thus the inhibition of acetyl-CoA synthesis and/or metabolism leads to disorder in many processes. The effect of dimepiperate on metabolic reactions in which acetyl-CoA is involved should therefore be investigated further.

Acknowledgement : The authors wish to thank Mitsubishi Petrochemical Co., Ltd. for providing dimepiperate technical.

\section{References}

1) Ashton, F. M., O. T. DeVilliers, R. K. Glenn and W.B. Duke 1977. Localization of metabolic sites of action of herbicides. Pest. Biochem. Physiol, 7, 122-141.

2) Dauson, J.H. 1963. Development of barnyardgrass seedlings and their response to EPTC. Weed 11, 60-66.

3) Donald, W. W., R.S. Fawcett and R.G. Harvey 1979. EPTC effects on corn (Zea mays) growth and endogenous gibberellins. Weed Sci. 27, 122127.

4) Fuerst, E.P. 1987. Understanding the mode of action of the chloroacetamide and thiocarbamate herbicides. Weed Technol. 1, 270-277.

5) Hosaka, H. and M. Kubota-Takagi 1987. Biochemical effects of sethoxydim in excised root tips of corn (Zea mays). Weed Sci. 35, 612-618.

6) Ikeda, K. 1982. Herbicidal property of a thiocarbamate herbicide, MY-93. Chemical Regulation of Plants 17, 163-169 (in Japanese).

7) Ikeda, K. and K. Sugaya 1989. Safening action of dimepiperate on herbicides inhibiting root growth of rice plant. Weed Res. (Japan) 34, 37-46 (in Japanese with English summary).

8) Kimura, I., N. Ichizen and S. Matsunaka 1971. Mode of action of an herbicide benthiocarb. Weed Res. (Japan) 12, 54-59 (1971) (in Japanese with English summary).

9) Matsumoto, H. and K. Ishizuka 1980. Herbicidal selectivity of foliar-applied simetryn. Weed Res. (Japan) 25, 185-193.

10) Matsumoto, H. and K. Ishizuka 1982. Effects of simetryn on the photochemical reactions of isolated chloroplasts of rice and barnyardgrass plants. Weed Res. (Japan) 27, 91-97.

11) Prakash, T.R., P. M. Swamy and D.D. K. Prasad 1990. Selective inhibition of porphyrin biosynthe- 
sis by benthiocarb (Saturn) in rice and barnyardgrass seedlings. Pest. Biochem. Physiol. 36, 29-34.

12) Wilkinson, R.E. and D. Ashley 1979. EPTC induced modification of gibberellin biosynthesis. Weed Sci. 27, 270-274.
13) Wilkinson, R.E. and T.H. Oswald 1987. S-ethyl dipropylthiocarbamate (EPTC) and 2,2-dichloro$\mathrm{N}, \mathrm{N}$-di-2-propenylacetamide (dichlormid) inhibitions of synthesis of acetyl-coenzyme A derivatives. Pest. Biochem. Physiol. 28, 38-43.

\section{チオカーバメート系除草剤ジメピペレートの植 物代謝系に対する作用}

松本 宏*·西 聖子*·石塚皓造*

\section{摘 要}

除草剤ジメピペレート (S-1-methyl-1-phenylethyl piperidine-1-carbothioate）の作用機構を明らかにす る端緒として, 種々の植物に対する除草効果と, 植物 の主要代謝系に及ぼす影響を調べた。

ジメピペレートは供試した単子葉植物の中で選択性 を示した。イネ(Oryza sativa cv. Nipponbare), お よびトウモロコシ (Zea mays cv. honeybantam) は より抵抗性, タイヌビエ (Echinochloa oryzicola), メヒシバ(Digitaria adscendens) はより感受性であっ た (Fig. 1 A)。双子葉植物はキュウリ (Cucumis sativus cv. Shimosirazujibai), トマト (Lycoperisicon esculentum cv. Toyofuku), アズキ(Phaseolus radiatus cv. Waseazuki), ダイコン(Raphanus sativus cv. Tokinashi)を供試したが, 全体的にジメピペレー トに対して抵抗性であり，種間差は単子葉植物より小 さかった (Fig. 1 B)。

感受性植物であるタイヌビエの展開中の第 4 葉から 切り出した葉片を用いて，植物の主要代謝系に対する

\footnotetext{
* 筑波大学応用生物化学系
}

ジメピペレートの影響を調べた。これは，放射能標識 した各代謝系に特有の前駆体を用いて，それらの葉 片への吸収と代謝系への取り込みをジメピペレート $\left(10^{-5} \mathrm{M}, 10^{-6} \mathrm{M}\right)$ の存在下で測定することにより行っ た。

ロイシンの葉片への吸収とタンパク画分への取り込 みは，120分までは影響を受けなかったが，10 $10^{-5} \mathrm{M}$, 240分の処理でわずかに減少した (Fig. 2)。ウリジン とチミジンの葉片への吸収と, それぞれ RNA, DNA 画分への取り込みは，用いた条件下では全く阻害され なかった (Fig. 3,Fig.4)。グルコースの吸収と取り込 みで調べた細胞壁の合成系はタンパク合成と同様に $10^{-5} \mathrm{M}, 240$ 分でのみわずかに阻害された(Fig. 5)。ア セテートの葉片への吸収と脂質画分への取り込みは, 処理後 30 分よいう短時間内から $10^{-6} \mathrm{M}$ でも阻害がみ られ，調べた代謝系の中ではこの脂質の合成系がジメ ピペレートに最も敏感な系として見い出された(Fig. 6 , Table 1)。またこの阻害は真核細胞の脂質生 合成阻 害剤として知られているセルレニンと同程度であった。 また光合成と呼吸はジメピペレートで全く阻害を受け なかった (Fig. 7)。

これらの結果から脂質の合成系にジメピペレートの 作用点が含まれる可能性が示され，脂質の合成系の諸 反応への影響の検討の必要性が指摘された。

キーワード : チオカーバメート系除草剤, ジメピペレ 一ト, 選択性, 作用機構, 脂質合成阻害 